Marquette University

e-Publications@Marquette

$1-1-2006$

Vested with Adam's Glory: Moses as the Luminous Counterpart of Adam in the Dead Sea Scrolls and the Macarian Homilies

Andrei Orlov

Marquette University, andrei.orlov@marquette.edu

Published Version. Christian Orient, Vol. 4, No. 10 (2006): 498-513. DOI. (C) 2006 Christian Orient. 
Andrei A. Orlov

\section{Vested with Adam's Glory: Moses as the Luminous Counterpart of Adam in the Dead Sea Scrolls and in the Macarian Homilies}

[Published in: "Mémorial Annie Jaubert (1912-1980)" Xristianskij Vostok 4.10 (2002) 740-755].

\section{Two Luminaries}

In the group of the Dead Sea Scrolls fragments known under the title the Words of the Luminaries (4Q504), ${ }^{1}$ the following passage about the glory of Adam in the Garden of Eden can be found:

... [ ... Adam,] our [fat]her, you fashioned in the image of [your] glory ([äë] ãåë úâ ãá äúøöé) [...] [... the breath of life] you [b]lew into his nostril, and intelligence and knowledge [...] [... in the gard]en of Eden, which you had planted. You made [him] govern [...] [...] and so that he would walk in a glorious land... [...] [...] he kept. And you imposed on him not to tu[rn away...] [...] he is flesh, and to dust $[\ldots]$...

Later in $4 Q 504$, this tradition about Adam's former glory follows with a reference to the luminosity bestowed on another human body--the glorious face of Moses at his encounter with the Lord at Sinai:

${ }^{1}$ On the Words of Luminaries, see: M. Baillet, Un receuil liturgique de Qumrân, grotte 4; 'Les Paroles des Luminaries' // Revue biblique 67 (1961) 195-250; IDEM, Remarques sur l'édition des Paroles des Luminaires // RevQ 5 (1964) 23-42; IDEM, Qumran Grotte 4 III (4Q482-520) (DJD, 7; Oxford, 1982); E. Glickler Chazon, "Words of the Luminaries" (4QDibHam): A Liturgical Document from Qumran and Its Implications (Ph.D. dissertation, Hebrew University, Jerusalem, 1991); IDEM, 4QDibHam: Liturgy or Literature? // RevQ 15 (1991-2) 447-55; IDEM, 'Dibre Hammêorot'; Prayer for the Sixth Day (4Q504 1-2 v-vi) // Prayer from Alexander to Constantine: A Critical Anthology (eds. M. Kiley et al.; London, 1997) 23-27; C.A. Evans, Aspect of Exile and Restoration in the Proclamation of Jesus and the Gospels // Exile: Old Testament, Jewish and Christian Concepts (ed. J.M. Scott; Leiden, 1997) (JSJSup., 56) 308-09; D. Falk, Daily, Sabbath, and Festival Prayers in the Dead Sea Scrolls (Leiden, 1988) (STDJ, 27) 59-94; F. García Martínez and Eibert J.C. Tigchelaar (eds.), The Dead Sea Scrolls Study Edition (2 vols.; LeidenNew York-Köln, 1997) 2.1008-1019; K.G. Kuhn, Nachträge zur Konkordanz zu den Qumrantexten // RevQ 4 (1963) 163-234; B. Nitzan, Qumran Prayer and Religious Poetry (Leiden, 1994) (STDJ, 12); D.T. Olson, Words of the Lights (4Q504-4Q506) // The Dead Sea Scrolls. Hebrew, Aramaic, and Greek Texts with English Translation. Vol. 4A: Pseudepigraphic and Non-Masoretic Psalms and Prayers (eds. J.H. Charlesworth and H.W.L. Rietz; Tübingen/Louisville, KY, 1997) 107-53; É. Puech, La Croyance des Esséniens en la Vie Future (2 vols.; Paris, 1993) 2.563-568.

${ }^{2}$ F. García Martínez and Eibert J.C. Tigchelaar (eds.), The Dead Sea Scrolls Study Edition (2 vols.; Leiden; New York; Köln, 1997) 2.1008-1009. 
... [...Re]member, please, that all of us are your people. You have lifted us wonderfully [upon the wings of] eagles and you have brought us to you. And like the eagle which watches its nest, circles [over its chicks,] stretches its wings, takes one and carries it upon [its pinions] [...] we remain aloof and one does not count us among the nations. And [...] [...] You are in our midst, in the column of fire and in the cloud [...] [...] your [hol]y [...] walks in front of us, and your glory is in [our] midst ([åo]]ëåúá äëãåäëå [...] [...] the face of Moses (äùà é̂̂), [your] serv[ant]... ${ }^{3}$

Two details are intriguing in these descriptions. First, the author of $4 Q 504$ appears to be familiar with the lore about the glorious garments of Adam, the tradition according to which first humans had luminous attires in Eden before their transgression.

Second, the author seems to draw parallels between the glory of Adam and the glory of Moses' face. ${ }^{4}$ The luminous face of the prophet might represent in this text an alternative to the lost luminosity of Adam and serve as a new symbol of God's glory once again manifested in the human body. It appears, therefore, that in $4 Q 504$, traditions about Adam's glory and Moses' glory are creatively juxtaposed with each other. Unfortunately, the fragmentary character of the Qumran document does not allow to grasp the full scope and intentions of the author(s) of $4 Q 504$ in making such juxtapostion. To understand this juxtapostion better, research must proceed to other sources where the association between the glory of Adam and Moses was made more explicit. One of such sources includes the Macarian Homilies, where the author vividly accentuates this association. However,

\footnotetext{
${ }^{3}$ F. García Martínez and Eibert J.C. Tigchelaar (eds.), The Dead Sea Scrolls Study Edition, 2.1008-1009.

${ }^{4}$ On Moses traditions, see: R. Bloch, Die Gestalt des Moses in der rabbinischen Tradition // Moses in Schrift und Überlieferung (Düsseldorf, 1963) 95-171; G.W. Coats, Moses: Heroic Man, Man of God (Sheffield, 1988) (JSOTSup., 57); Death, Ecstasy, and Other Worldly Journeys (eds. J.J. Collins, M. Fishbane; Albany, 1995); C. N. T. Fletcher-Louis, Luke-Acts: Angels, Christology and Soteriology (Tübingen, 1997); J. Fossum, The Name of God and the Angel of the Lord: Samaritan and Jewish Concepts of Intermediation and the Origin of Gnosticism (Tübingen, 1985) 90-94; IDEM, The Image of the Invisible God (Göttingen, 1995) (Novum Testamentum et Orbis Antiquus, 30); S.J. Hafemann, Moses in the Apocrypha and Pseudepigrapha: A Survey // Journal for the Study of the Pseudepigrapha 7 (1990) 79-104; P.W. van der Horst, Moses' Throne Vision in Ezekiel the Dramatist // Journal of Jewish Studies 34 (1983) 21-29; H. Jacobsen, The Exagoge of Ezekiel (Cambridge, 1983); W.A. Meeks, Moses as God and King // Religions in Antiquity: Essays in Memory of Erwin Ramsdell Goodenough (ed. Jacob Neusner; Leiden, 1968); IDEM, The Prophet-King: Moses Traditions and the Johannine Christology (Leiden, 1967); A. Orlov, Ex 33 on God's Face: A Lesson from the Enochic Tradition // Seminar Papers 39, Society of Biblical Literature Annual Meeting 2000 (Atlanta, 2000) 130-147; A. Schalit, Untersuchungen zur Assumptio Mosis (Leiden, 1989); J.P. Schultz, Angelic Opposition to the Ascension of Moses and the Revelation of the Law // Jewish Quarterly Review 61 (1970-71) 282-307; J. Tromp, The Assumption of Moses: A Critical Edition with Commentary (Leiden, 1993).
} 
before our research proceeds to a detailed analysis of the Adam/Moses connection in the Dead Sea Scrolls and in the Macarian homilies, a short introduction to the Jewish, Samaritan, and Christian materials about the glorious garments of Adam and the glorious face of Moses is needed.

\section{The Background: The Garments of Light}

The Biblical passages found in Gen 1:26-27 and Gen 3:21 represent two pivotal starting points for the subsequent Jewish and Christian reflections on the glorious garments of Adam and Eve. Gen 1:26 describes the creation of human being(s) after the likeness (úẫã) of the image (í ì ö) of God. It is noteworthy that Gen 1:26-27 refers to the í ì ö (tselem) of Adam, the luminous image of God's glory according to which Adam was created. ${ }^{5}$ The particular interest in Gen 1:26 is that Adam's tselem was created after God's own tselem (åà ì öá) (literally "in our tselem"), being a luminous "imitation" of the glorious tselem of God. Some scholars argue that the likeness that Adam and God shared was not physicality--in the usual sense of having a body--but rather luminescence. ${ }^{6}$

\footnotetext{
${ }^{5}$ For discussions about the luminous garment/image/body of Adam, see: David H. Aaron, Shedding Light on God's Body in Rabbinic Midrashim: Reflections on the Theory of a Luminous Adam // Harvard Theological Review 90 (1997) 299-314; S. Brock, Clothing Metaphors as a Means of Theological Expression in Syriac Tradition // Typus, Symbol, Allegorie bei den östlichen Vätern und ihren Parallelen im Mittelalter (Regensburg, 1982) (Eichstätter Beiträge 4) 11-40; A.D. De Conick and J. Fossum, Stripped before God: A New Interpretation of Logion 37 in the Gospel of Thomas // VC 45 (1991) 141; A. D. De Conick, Seek to See Him: Ascent and Vision Mysticism in the Gospel of Thomas (Leiden, 1996) (SVC, 33); L. Ginzberg, The Legends of the Jews (7 vols.: Philadelphia, 1955) 5.97; Alon Goshen Gottstein, The Body as Image of God in Rabbinic Literature // Harvard Theological Review 87 (1994) 171-95; B. Murmelstein, Adam, ein Beitrag zur Messiaslehre // Wiener Zeitschrift für die Kunde des Morgenlandes 35 (1928) 255; W. Staerk, Die Erlösererwartung in den östlichen Religionen (Stuttgart and Berlin, 1938$) 11$.

${ }^{6}$ David Aaron, Shedding Light on God's Body, 303.
} 
The Tarqums, the Aramaic renderings of the Hebrew Bible, also attest to the prelapsarian luminosity of Adam and Eve in the Garden of Eden. The Biblical background for such traditions includes the passage from Gen 3:21, where "the Lord God made for Adam and his wife garments of skin and clothed them." The Targumic traditions, both Palestinian ${ }^{7}$ and Babylonian, ${ }^{8}$ read, instead of "garments of skin," "garments of glory." This Targumic interpretation is reinforced by Rabbinic sources. One of them can be found in Genesis Rabbah 20:12, which tells that the scroll of Rabbi Meir reads "garments of light" (øå̀ úåáü) instead of "garments of skin" (øåò úåúë): "In R. Meir's Torah it was found written, 'Garments of light: this refers to Adam's garments, which were like a torch [shedding radiance], broad at the bottom and narrow at the top."'9 It is usually understood that Gen 3:21 refers to God's clothing Adam and Eve's nakedness after the Fall. S. Brock, however, argues that sufficient evidence exist to suggest that there also was another way of understanding the time reference of Gen 3:21.

${ }^{7}$ In Targum Pseudo-Jonathan on Gen 3:21 the following tradition can be found: "And the Lord God made garments of glory for Adam and for his wife from the skin which the serpent had cast off (to be worn) on the skin of their (garments of) fingernails of which they had been stripped, and he clothed them." Targum Pseudo-Jonathan: Genesis (tr. M. Maher, M.S.C.; Collegeville, 1992) (The Aramaic Bible, 1B) 29. Targum Neofiti on Gen 3:21 unveils the similar tradition: "And the Lord God made for Adam and for his wife garments of glory ( $\varnothing \div$ åa ã ïêåà ), for the skin of their flesh, and he clothed them." Targum Neofiti 1: Genesis (tr. M. McNamara, M.S.C.; Collegeville, 1992) (The Aramaic Bible: 1A) 62-63; A. Díez Macho, Neophiti 1: Targum Palestinense MS de la Biblioteca Vaticana (Madrid-Barcelona, 1968) 1.19. The Fragmentary Targum on Gen 3:21 also uses the imagery of the glorious garments: "And He made: And the memra of the Lord God created for Adam and his wife precious garments ( $\varnothing \div$ :ê iêâaì ) [for] the skin of their flesh, and He clothed them." M.I. Klein, The Fragment-Targums of the Pentateuch according to Their Extant Sources (2 vols.; Rome, 1980) (AB, 76) I.46; II.7.

${ }^{8}$ Targum Onqelos on Gen 3:21 reads: "And the Lord God made for Adam and his wife garments

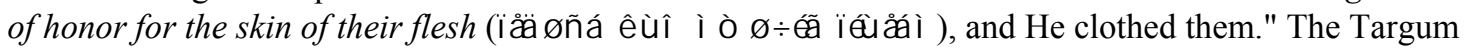
Onqelos to Genesis (tr. B. Grossfeld; Wilmington, 1988) (The Aramaic Bible, 6) 46; The Bible in Aramaic Based on Old Manuscripts and Printed Texts (ed. A. Sperber; Leiden, 1959) I.5.

${ }^{9}$ Cf. H. Freedman and M. Simon (tr.), Midrash Rabbah (10 vols.; London, 1939) 1. 171. 
According to this alternative understanding the verbs are to be taken as pluperfects, referring to the status of Adam and Eve at their creation before the Fall. ${ }^{10}$

It is noteworthy that in the later Jewish and Samaritan sources, the story about Adam's luminous garments is often mentioned in conjunction with Moses' story. In these materials, Moses is often depicted as a luminous counterpart of Adam.

Jarl Fossum and April De Conick successfully demonstrated the importance of the Samaritan materials for understanding the connection between the "glories" of Adam and Moses. The Samaritan texts insist that when Moses ascended to Mount Sinai, he received the image of God which Adam cast off in the Garden of Eden. ${ }^{11}$ According to Memar Marqa, Moses was endowed with the identical glorious body as Adam. ${ }^{12}$ Memar Marqa 5.4 tells that:

He [Moses] was vested with the form which Adam cast off in the Garden of Eden; and his face shone up to the day of his death. ${ }^{13}$

The Adam/Moses connection also looms large in the Rabbinic sources. Alon Goshen Gottstein stresses that "the luminescent quality of the image (tselem) is the basis for comparison between Moses and Adam in several rabbinical materials." 14

Deuteronomy Rabbah 11.3 offers important witness to the Adam/Moses conection. It includes the following passage in which two "luminaries" argue whose glory is the greatest:

Adam said to Moses: "I am greater than you because I have been created in the image of God." Whence this? For it is said, "and God created man in his own image" (Gen. 1,27). Moses replied to him: "I

${ }^{10} \mathrm{~S}$. Brock, Clothing Metaphors as a Means of Theological Expression in Syriac Tradition, 14.

${ }^{11} \mathrm{~J}$. Fossum, The Name of God and the Angel of the Lord: Samaritan and Jewish Concepts of Intermediation and the Origin of Gnosticism (Tübingen, 1985) 93; A. D. De Conick, Seek to See Him: Ascent and Vision Mysticism in the Gospel of Thomas, 159.

${ }^{12}$ Fossum, The Name of God, 94.

${ }^{13}$ J. Macdonald, Memar Marqah. The Teaching of Marqah (Berlin, 1963) (BZAW, 83) 209.

${ }^{14}$ Alon Goshen Gottstein, The Body as Image of God in Rabbinic Literature, 182. 
am far superior to you, for the honor which was given to you has been taken away from you, as it is said: but man (Adam) abideth not in honor, (Ps. XLIX, 13) but as for me, the radiant countenance which God gave me still remains with me." Whence? For it is said: "his eye was not dim, nor his natural force abated" (Deut. 34,7). ${ }^{15}$

\section{Goshen Gottstein draws attention to another significant midrashic passage from}

\section{Midrash Tadshe 4, in which Moses poses Adam's luminous counterpart. The tradition}

tells that

...in the likeness of the creation of the world the Holy One blessed be he performed miracles for Israel when they came out of Egypt... In the beginning: "and God created man in his image," and in the desert: "and Moshe knew not that the skin of his face shone."16

It is also remarkable that later Rabbinic materials often speak of the luminosity of Adam's face, ${ }^{17}$ the feature that might point to the influence of the Adam-Moses connection. Thus, as an example, in Leviticus Rabbah 20.2, the following passage can be found:

Resh Lakish, in the name of R. Simeon the son of Menasya, said: The apple of Adam's heel outshone the globe of the sun; how much more so the brightness of his face! Nor need you wonder. In the ordinary way if a person makes salvers, one for himself and one for his household, whose will he make more beautiful? Not his own? Similarly, Adam was created for the service of the Holy One, blessed be He, and the globe of the sun for the service of mankind. ${ }^{18}$

Genesis Rabbah 11 also focuses, not on Adam's luminous garments, but rather on

his glorious face:

Adam's glory did not abide the night with him. What is the proof? But Adam passeth not the night in glory (Ps. XLIX, 13). The Rabbis maintain: His glory abode with him, but at the termination of the Sabbath He deprived him of his splendor and expelled him from the Garden of Eden, as it is written, Thou changest his countenance, and sendest him away (Job XIV, 20). ${ }^{19}$

${ }^{15}$ H. Freedman and M. Simon (tr.), Midrash Rabbah (10 vols.; London, 1939) 7.173.

${ }^{16}$ Cf. Adolph Jellinek, Bet ha-Midrash (6 vols.; Jerusalem, 1967) 3. 168.

${ }^{17}$ According to Jewish sources, the image of God was reflected especially in the radiance of Adam's face. See: Fossum, The Name of God, 94; J. Jervell, Imago Dei (Göttingen, 1960) (FRLANT, 76) 45.

${ }^{18}$ H. Freedman and M. Simon (tr.), Midrash Rabbah (10 vols.; London, 1939) 4.252.

${ }^{19}$ H. Freedman and M. Simon (tr.), Midrash Rabbah (10 vols.; London, 1939) 1.81. 
Despite the importance of these late Rabbinic passages linking the luminosity of Adam's body and Moses' face, the chronological boundaries of these evidences are difficult to establish. Rabbinic attestations to the Adam/Moses connection are also very succinct and sometimes lack any systematic development.

Much more extensive expositions of the traditions about Moses as the heavenly counterpart of Adam can be found in the writings of the fourth century Christian author, the Syrian father, known to us as Pseudo-Macarius.

\section{Adam and Moses in the Macarian Homilies}

It is difficult to overestimate the importance of Adam/Moses "glory" typologies for the theological enterprise of the Macarian Homilies ${ }^{20}{ }^{2}$ The symbolism of the divine light seems to stay at the center of the theological world of the Syrian father. ${ }^{21}$ Adam's luminosity in the Garden and Christ's luminosity at Mount Tabor serve for PseudoMacarius as important landmarks of the eschatological Urzeit and Endzeit. In dealing with these stories of the fall and the restoration of the divine light in human nature, Macarian writings also employ another important traditional symbol of the manifestation

\footnotetext{
${ }^{20}$ This feature of the Macarian Homilies serves as additional proof of the close relationship between Pseudo-Macarius and the various Syriac developments in which the theme of Adam's garments plays an important theological role. S. Brock notes the extensive usage of the "clothing" metaphors in the Syriac tradition. He shows that this imagery is closely connected with Adam Christology: "...the first Adam loses the robe of glory at the Fall; the second Adam puts on the body of the first Adam in order to restore the robe of glory..." S. Brock, Clothing Metaphors as a Means of Theological Expression in Syriac Tradition, 16.

${ }^{21}$ The traditions about the glorious garments of Adam and Eve were widespread in the Syriac sources. [For a detailed discussion of this subject, see: A. D. De Conick, Seek to See Him: Ascent and Vision Mysticism in the Gospel of Thomas, 157-172; S. Brock, Clothing Metaphors as a Means of Theological Expression in Syriac Tradition, 11-38]. It is possible that the early Syrian authors gained access to such traditions through their familiarity with the Targums, the Aramaic renderings of the Hebrew Bible. The Macarian Homilies, which were connected with the Syrian milieu, demonstrate that their author was exposed to a great variety of the Jewish and Christian traditions about the luminous garments of the first humans.
} 
of the divine glory in humans--Moses' luminous face. In his employment of the

Adam/Moses connection, the author of the Macarian Homilies reveals profound

knowledge of the Jewish and Christian esoteric traditions about the glorious

manifestations of Adam and Moses.

The story of Adam serves for the homilist as the starting point of his theology of the divine light. Thus, from the homily II. $12^{22}$ the reader learns that "Adam, when he transgressed the commandment, lost two things. First, he lost the pure possession of his nature, so lovely, created according to the image and likeness of God

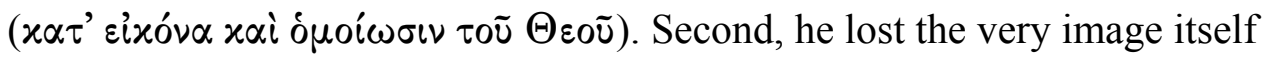

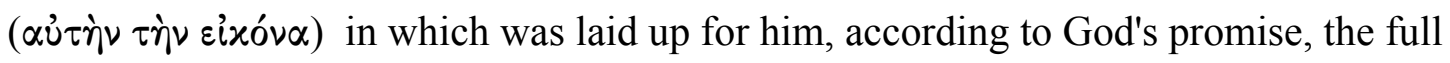
heavenly inheritance"(II.12.1). ${ }^{23}$ Further, another important passage in the same homily

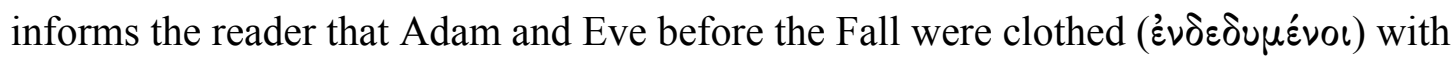
God's glory in place of clothing (II.12.8). ${ }^{24}$ The homily shows a certain continuity between Adam's "very image itself" and his glorious clothing. An important detail in the narrative is that the homilist makes a distinction between Adam's nature, created after the image and likeness of God, and Adam's "very image itself;" he speaks of them as of two separate entities which were lost during the Fall. This subtle theological distinction

22 There are four Byzantine medieval collections of Macarian Homilies. Three of them appeared in critical editions. Collection I was published in Makarios/Simeon: Reden und Briefe. Die Sammlung I des Vaticanus Graecus 694 (B) (2 vols.; ed. H. Berthold, Berlin, 1973). Collection II appeared in H. Dörries, E. Klostermann, and M. Kroeger, Die 50 Geistlichen Homilien des Makarios (Berlin, 1964) (PTS, 4).

Collection III appeared in Neue Homilien des Makarios/Simeon aus Typus III (eds. E. Klostermann and H. Berthold; Berlin, 1961) (TU, 72) and Pseudo-Macaire. Oeuvres spirituelles. Vol. I: Homelies propres a la Collection III (ed. V. Desprez; Paris, 1980) (SC, 275). In references to the Macarian homilies, the first uppercase Roman numeral will designate a Collection, and the following Arabic numerals will designate a specific homily and its subsections.

${ }^{23}$ Pseudo-Macarius, The Fifty Spiritual Homilies and the Great Letter (tr. G.A. Maloney, S.J.; New York, 1992) 97. H. Dörries et al., Die 50 Geistlichen Homilien des Makarios (Berlin, 1964) (PTS, 4) 107-8.

\footnotetext{
${ }^{24}$ Pseudo-Macarius, The Fifty Spiritual Homilies and the Great Letter, 100.
} 
shows the author's familiarity with the Jewish aggadic traditions about the tselem of Adam--the luminous image of God's glory according to which the first human being was created. The Macarian association of Adam's garments and his creation after the luminous image of God points us again to the Qumran passage from 4Q504, where Adam is depicted as the one who was "fashioned" in the image of God's glory. It should be noted that besides this reference to "image," both texts entertain several other parallels that reveal similarities between the Adamic story in the Macarian Homilies and the

\section{Adamic traditions at Qumran.}

First, the Qumran Adamic account in 4Q504 8 is distinctive in that it connects Adam's glorious state ${ }^{25}$ with his ability to exercise dominion ${ }^{26}$ over the rest of creation. 4Q504 8 reads:

... [ ... Adam,] our [fat]her, you fashioned in the image of [your] glory ...You made [him] govern [...] [...] and so that he would walk in a glorious land... ${ }^{27}$

Macarian writings also employ the same juxtaposition by linking Adam's glory with his capacity to exercise power over the created order by giving names to various things. ${ }^{28}$ The Homily II.12.6 tells that:

...As long as the Word of God was with him, he [Adam] possessed everything. For the Word himself was his inheritance, his covering, and a glory that was his defense (Is 4:5). He was his teaching. For he taught him how to give names to all things: "Give this name of heaven, that the sun; this the moon; that earth; this a bird; that a beast; that a tree." As he was instructed, so he named them. ${ }^{29}$

${ }^{25}$ Cf. 2 Enoch 30:11-12 (the longer recension): "And on the earth I assigned him to be a second angel, honored and great and glorious. And I assigned him to be a king, to reign on the earth, and to have my wisdom." F. Andersen, 2 (Slavonic Apocalypse of) Enoch // The Old Testament Pseudepigrapha (ed. J. H. Charlesworth; New York, 1985 [1983]) 1.152.

${ }^{26}$ E. Glickler Chazon, The Creation and Fall of Adam in the Dead Sea Scrolls // The Book of Genesis in Jewish and Oriental Christian Interpretation. A Collection of Essays (eds. J. Frishman and L. Van Rompay; Lovain, 1997) (Traditio Exegetica Graeca, 5) 15.

${ }^{27}$ F. García Martínez and Eibert J.C. Tigchelaar (eds.), The Dead Sea Scrolls Study Edition (2 vols.; Leiden; New York; Köln, 1997) 2.1009.

${ }^{28}$ Cf. also Gen 1:26.

${ }^{29}$ Pseudo-Macarius, The Fifty Spiritual Homilies and the Great Letter, 99. 
A second important detail that connects the Adamic tradition at Qumran with Macarian writings is that the luminous image (tselem) of Adam in the Macarian Homilies is termed as "the full heavenly inheritance." ${ }^{30}$ In II.12.1, it is also associated with a very valuable estate:

...he lost the very image itself in which was laid up for him, according to God's promise, the full heavenly inheritance $(x \lambda \eta p o v o \mu i \alpha)$. Take the example of a coin bearing the image of the king. If it were mixed with a false alloy and lost its gold content, the image also would lose its value. Such, indeed, happened to Adam. A very great richness and inheritance was prepared for him. It was as though there were a large estate and it possessed many sources of income. It had a fruitful vineyard; there were fertile fields, flocks, gold and silver. Such was the vessel of Adam before his disobedience like a very valuable estate. $^{31}$

The terminology found in this Macarian passage seems allude to the Qumran Adamic materials, which also refer to Adam's "inheritance." Thus, the Qumran Pesher on Psalms (4Q171) contains a reference to the inheritance of Adam (í ãà úì çđ) which the Israelites will have in the future:

...those who have returned from the wilderness, who will live for a thousand generations, in salva[tio]n; for them there is all the inheritance of Adam (í ãà úì çð), and for their descendants for ever... ${ }^{32}$

In previous studies, scholars ${ }^{33}$ noted that this passage from $4 Q 171$ seems to refer to an eschatological period characterized in part by a reversal of the Adamic curse and the restoration of the glory ${ }^{34}$ of Adam. ${ }^{35}$

\footnotetext{
${ }^{30}$ Pseudo-Macarius, The Fifty Spiritual Homilies and the Great Letter, 97.

${ }^{31}$ Pseudo-Macarius, The Fifty Spiritual Homilies and the Great Letter, 97.

${ }^{32}$ 4Q171 3:1-2. F. García Martínez and Eibert J.C. Tigchelaar (eds.), The Dead Sea Scrolls Study Edition, 1.345 .

${ }_{33}^{3}$ M.O. Wise, 4QFlorilegium and the Temple of Adam // RevQ 15 (1991-92) 128.
} 
It is important to note that the Macarian passage links the inheritance with the large estate which includes a vineyard. The reference to the vineyard is intriguing since in $4 Q 171$ the term, the "inheritance" of Adam, is closely associated with the Temple ${ }^{36}$ and the Temple mountain. ${ }^{37}$

The foregoing analysis shows that the theme of Adam's heavenly garments plays an important role in the theological universe of the Macarian Homilies. The homilist, however, does not follow blindly these ancient traditions, but, incorporates them into the fabric of the Christian story. The Adamic narrative, therefore, represents an essential part of the Macarian "glory" Christology, where the lost luminous garment of the First Adam has to be restored by the glory of the Second Adam, Christ. The Second Adam thus must put on the body of the first Adam in order to restore the lost clothes of the divine light, which now has to be acquired by the believers at their resurrection.

However, in Macarian writings this "glory" Christology is not simply confined to the Adam-Christ dichotomy but includes a third important element, namely, the story of Moses, whose glorious face serves as the prototype for the future glory of Christ at the Transfiguration. ${ }^{38}$ The radiance of the patriarch's face remains in the Macarian Homilies to be the mediator between the former glory of Adam lost in the Paradise and the future

${ }^{34} \mathrm{Cf}$. $C D$ 3:20 "Those who remain steadfast in it will acquire eternal life, and all the glory of Adam (í ãà ãåë ì ëå is for them." F. García Martínez and Eibert J.C. Tigchelaar (eds.), The Dead Sea Scrolls Study Edition, 1.555.

${ }^{35} \mathrm{M}$. Wise observes that this description in $4 Q 171$ "jibes completely with the concept of í ãà ãåä in CD." M.O. Wise, 4QFlorilegium and the Temple of Adam // RevQ 15 (1991-92) 128.

${ }^{36}$ On the identification of Eden with the Sanctuary, see: G.J. Brooke, Miqdash Adam, Eden and the Qumran Community // Gemeinde ohne Tempel/Community without Temple. Zur Substituierung und Transformation des Jerusalemer Tempels und seines Kults im Alten Testament, antiken Judentum und frühen Christentum (Tübingen, 1999) 285-299

${ }^{37} 4 Q 1713: 11$ "...they will inherit the high mountain of Isra[el and] delight [in his] holy [mou]ntain." F. García Martínez and Eibert J.C. Tigchelaar (eds.), The Dead Sea Scrolls Study Edition, 1.345 . 
glory of Christ, which will eventually be manifested in the resurrected bodies of the saints. Thus, in the Homily II.5.10-11, Macarius tells about the Moses glorious face as the prototype of the future glory:

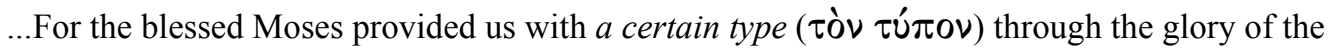
Spirit which covered his countenance upon which no one could look with steadfast gaze. This type anticipates how in the resurrection of the just the body of the saints will be glorified with a glory which even now the souls of the saintly and faithful people are deemed worthy to possess within, in the indwelling of the inner man... ${ }^{39}$

In his presentation of the shining appearance of Moses, the homilist, however, makes a clear distinction between the glory of Moses at Sinai and the glory of Christ at the Transfiguration. Moses' glory is only a "prototype" of God's "true" glory. Macarius' understanding of Moses' glory as the prototype ( $\tau \dot{\pi} \pi \circ \varsigma$ ) or the figure of the "true glory" is observable, for example, in the Homily II.47.1:

...The glory of Moses which he received on his countenance was a figure of the true glory ( $\tau \dot{u} \pi 0 \varsigma \tilde{\eta} \nu \tau \tilde{\eta} \varsigma \dot{\alpha} \lambda \eta \theta \imath \tilde{\eta} \varsigma \delta o^{\prime} \xi \eta \zeta$ ). Just as the Jews were unable "to look steadfastly upon the face of Moses" (2 Cor 3:7), so now Christians receive that glory of light in their souls, and the darkness, not bearing the splendor of the light, is blinded and is put to fight. ${ }^{40}$

Another feature of Moses' glorification is that Moses' luminous face was only "covered" with God's glory in the same way as the luminous garments covered the body of the first humans. According to Macarius, Moses' luminosity was not able to penetrate

${ }^{38}$ Here again Macarius draws on the established Christian tradition which can be traced to Pauline writings (esp. 2 Cor 3), where the glory of Moses and the glory of Christ are interconnected.

${ }^{39}$ Pseudo-Macarius, The Fifty Spiritual Homilies and the Great Letter, 74; Dörries, 62. The Homily II.5.11 repeats the same idea again: "In a double way, therefore, the blessed Moses shows us what glory true Christians will receive in the resurrection: namely, the glory of light and the spiritual delights of Spirit which even now they are deemed worthy to possess interiorly." Pseudo-Macarius, The Fifty Spiritual Homilies and the Great Letter, 74.

${ }^{40}$ Homily II.47.1. Pseudo-Macarius, The Fifty Spiritual Homilies and the Great Letter, 232; Dörries, 304. 
human nature and remove the inner garments of darkness bestowed by the devil on the human heart. ${ }^{41}$ In II.32.4, the Syrian father affirms that:

...Moses, having been clothed in the flesh, was unable to enter into the heart and take away the sordid garments of darkness. ${ }^{42}$

For Macarius, only the glory of Christ is able to remove the attire of darkness and "heal" the human heart. It is, therefore, observable that for the Syrian father the glory of Moses shows a greater typological affinity to the glory of Adam ${ }^{43}$ then to the glory of Christ.

${ }^{41}$ The Macarian motif of the garments of darkness bestowed by Satan on the first humans brings us to the connection between the Macarian Homilies and the Targumic traditions. It has been mentioned previously that the Syrian authors might have acquired their knowledge of the Jewish aggadic traditions about the luminosity of the garments of Adam and Eve via their familiarity with the Targumic texts. Some features of Adam's story found in the Macarian Homilies point in this direction. For example, the Homily II.1.7 tells that when "... Adam violated the command of God and obeyed the deceitful serpent he sold himself to the devil and that evil one put on Adam's soul as his garment - that most beautiful creature that God had fashioned according to his own image..." [Pseudo-Macarius, The Fifty Spiritual Homilies and the Great Letter, 41]. This motif of Adam being clothed with the evil one as his garment seems to allude to the Targumic tradition which attests to the fact that God made garments for Adam and Eve from the skin which the serpent had cast off. The Targum Pseudo-Jonathan on Gen 3:21 tells that: "And the Lord God made garments of glory for Adam and for his wife from the skin which the serpent had cast off (to be worn) on the skin of their (garments of) fingernails of which they had been stripped, and he clothed them." [Targum Pseudo-Jonathan: Genesis (tr. M. Maher, M.S.C.; Collegeville, 1992) (The Aramaic Bible, 1B) 29]. It seems, however, that the author of the Macarian Homilies substantially edits this Targumic tradition. In the Macarian Homilies, the garments of the devil become the attire of darkness in contrast to the Palestinian Targum, where they are depicted as the garments of light. On the garments of darkness, cf. also the Homily II.30.7: "In that day when Adam fell, God came walking in the garden. He wept, so to speak, seeing Adam and he said: 'After such good things, what evils you have chosen! After such glory, what shame you now bear! What darkness are you now! What ugly form you are! What corruption! From such light, what darkness has covered you!' When Adam fell and was dead in the eyes of God, the Creator wept over him. The angels, all the powers, the heavens, the earth and all creatures bewailed his death and fall. For they saw him, who had been given to them as their king, now become a servant of an opposing and evil power. Therefore, darkness became the garment of his soul, a bitter and evil darkness, for he was made a subject of the prince of darkness." Pseudo-Macarius, The Fifty Spiritual Homilies and the Great Letter, 192-93.

${ }^{42}$ Pseudo-Macarius, The Fifty Spiritual Homilies and the Great Letter, 198.

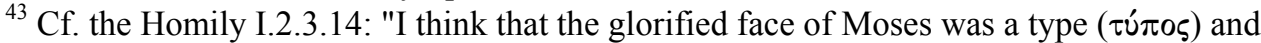
teaching of the first Adam, formed by the hands of God, which death saw and was wounded by it, not being able to look on it, and fearing that its kingdom would be dissolved and destroyed--which, with the Lord, did in fact occur." Alexander Golitzin, The Macarian Homilies from Collection I, 3 (forthcoming); Makarios/Simeon: Reden und Briefe. Die Sammlung I des Vaticanus Graecus 694 (B) (2 vols.; ed. H. Berthold, Berlin, 1973) 1.9. I am thankful to Father Alexander Golitzin for letting me use here his forthcoming English translation of the Macarian Homilies from Collection I. 
A decisive feature of the Macarian Homilies is that the homilist often emphasizes the connection between the luminosity of Adam's heavenly attire lost in the Paradise and the luminosity of Moses' face acquired on Mount Sinai. In the Macarian Homilies, the motif of Moses' glorious face seems to serve as a sign of the partial restoration of the former glory of Adam, ${ }^{44}$ the glorious garment of light in which Adam and Eve were clothed in the Garden of Eden before their transgression. Moses' glorious face is, therefore, viewed by the homilist as the counterpart of the glorious garment of Adam. The conflation of the two "glories," lost and acquired, is observable, for instance, in the Homily II.12. After the already mentioned Adamic narrative of Homily II.12, which tells how Adam lost his luminous status and "obeyed his darker side," Macarius sets before the reader the example of Moses as the one who "had a glory shining on his countenance." 45

\section{The Healing Motif}

The employment of Adam/Moses connection in the Qumran materials does not seem to be confined solely to $4 Q 504$. There is another important document which appears to entertain a similar connection. In the Qumran fragment $4 Q 374$, also known as the Discourse on the Exodus/Conquest Tradition, ${ }^{46}$ the portentous clause can be found

${ }^{44}$ Cf. the Homily I.2.3.14 "Now, I think that when the enemy saw the original glory of Adam on the face of Moses, he was wounded because [he understood that] his kingdom was going to be taken away." Alexander Golitzin, The Macarian Homilies from Collection I, 3 (forthcoming).

45 "...Indeed, the Word of God was his food and he had a glory shining on his countenance. All this, which happened to him, was a figure of something else. For that glory now shines splendidly from within the hearts of Christians. At the resurrection their bodies, as they rise, will be covered ( $\sigma x \varepsilon \pi \dot{\alpha} \zeta \varepsilon \tau \alpha \iota)$ with another vesture, one that is divine, and they will be nourished with a heavenly food." (II.12.14). Pseudo-Macarius, The Fifty Spiritual Homilies and the Great Letter, 102; Dörries, 114.

46 On 4Q374, see: C. Fletcher-Louis, 4Q374: A Discourse on the Sinai Tradition: The Deification of Moses and Early Christianity // Dead Sea Discoveries 3 (1996) 236-252; C.A. Newsom, 4Q374: A Discourse on the Exodus/Conquest Tradition // The Dead Sea Scroll: Forty Years of Research (eds. D. Dimant, and U. Rappaport; Leiden, 1992) (STDJ, 10) 40-52. On Moses pseudepigrapha in the DSS, see: J. Strugnell, Moses-Pseudepigrapha at Qumran: 4Q375, 4Q376, and Similar Works // Archaeology and 
which connects Moses' shining countenance ${ }^{47}$ at the Sinai encounter ${ }^{48}$ with the motif of healing. The passage unveils the following tradition: "[But] he (Moses) had pity with [...] and when he let his face shine for them for healing (àôøî ì ), they strengthened [their] hearts again...."49

In this passage, as in $4 Q 504$, God's glory is described to be manifested through Moses' shining face. It appears that the passage is related to the ongoing discussion about the luminosity of Moses and Adam. Here again, as in the case of $4 Q 504$, the evidence found in the Macarian Homilies helps to clarify the possible connection.

The Homily II.20 describes Christ as the true physician of human nature who can heal the human soul and adorn it with the garments of his grace. It is evident that the theme of healing is interwoven in the homily with the motif of the luminous garments. In unfolding this theme, the homilist, first, retells the Gospel story about the woman who was cured of the blood flow by touching of the garment of the Lord, and connects the motif of healing with the theme of the garments:

... and again just as the woman afflicted with an issue of blood believed truly and touched the hem of the garment of the Lord and immediately received a healing and the flow of the unclean fountain of blood dried up... ${ }^{50}$

Following the story of the healed woman, Macarius proceeds to the examples of Adam and Moses. It is not a coincidence that in this homily, as in 4Q504, Moses' name is mentioned in connection with the theme of healing. From the homily II.20.6, we learn

History in the Dead Sea Scrolls. The New York University Conference in Memory of Yigael Yadin (ed. L.H. Schiffman, Sheffield, 1990) (JSPSS, 8) 221-256.

${ }^{47}$ On the luminosity of the Moses face, see: M. Haran, The Shining of Moses's Face: A Case Study in Biblical and Ancient Near Eastern Iconography [Ex 34:29-35; Ps 69:32; Hab 3:4] // In the Shelter of Elyon (JSOP, 31; Sheffield, 1984) 159-73; W. Propp, The Skin of Moses' Face - Transfigured or Disfigured? // Catholic Biblical Quarterly 49 (1987) 375-386.

${ }^{48}$ Crispin Fletcher-Louis rightly observes that there is ample evidence that the passage from 4Q374 was concerned with the revelation at Sinai. Cf. C. Fletcher-Louis, 4Q374: A Discourse on the Sinai Tradition: The Deification of Moses and Early Christianity, 238.

${ }^{49}$ F. García Martínez and Eibert J.C. Tigchelaar (eds.), The Dead Sea Scrolls Study Edition, 2.740-741.

${ }^{50}$ Pseudo-Macarius, The Fifty Spiritual Homilies and the Great Letter, 151. 
that "indeed, Moses came, but he was unable to bring a perfect healing

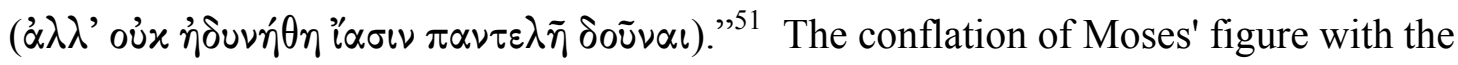
healing motif in the Macarian Homilies is intriguing since it might indicate that the author of the Homilies draws on the traditions similar to those that can be found in $4 Q 374 .^{52}$

The affinities between the healing motif found in the Macarian Homilies and in 4Q374 include another important feature. Both texts interpret healing to be the healing of the human heart. The Qumran material speaks that after the healing through Moses' shining countenance the hearts of the Israelites were "strengthened" again. 53 The Homily II.20.7 also links the motif of healing with the theme of the curing (or cleansing) of the human heart. It tells that "man could be healed only by the help of this medicine and thus could attain life by a cleansing of his heart by the Holy Spirit."54

It seems that in both excerpts (4Q374 and Macarian), the luminosity of Moses' face plays an important role. Although the Macarian passage does not directly refer to the shining face of Moses, the context of the passage, which deals with the garments of the Lord, indicates that in the Macarian Homilies the motif of "healing" is understood as the restoration of the former Adamic glory, the glorious garments with which the first humans were clothed in Eden before their transgression. The author of the Homilies seems to view Moses' shining face as an important step in the process of the recovery of the former divine glory once manifested in humans during their life in Paradise.

${ }^{51}$ Pseudo-Macarius, The Fifty Spiritual Homilies and the Great Letter, 151. Dörries, 190.

${ }^{52}$ Cf. also the Homily I.2.12.7-9: "...the devil, by means of a tree and serpent, used jealousy and trickery to deceive Adam and Eve, and arranged [for them] to be thrown out of Paradise, and brought them down from their purity and glory to bitter passions and death, and subsequently, having received from them the whole human race [to be] under his power, cased [it] to stray into every sin and defiling passion... by his inexpressible wisdom, God, making provisions for humanity, send forth Moses the healer to redeem the People through the wood of his staff....therefore half of piety was set aright through Moses, and half of the passions healed ( $(\dot{\alpha} \alpha \eta \eta)$..." Alexander Golitzin, The Macarian Homilies from Collection I, 9 (forthcoming); Makarios/Simeon: Reden und Briefe. Die Sammlung I des Vaticanus Graecus 694 (B) (2 vols.; ed. H. Berthold, Berlin, 1973) 1.24.

${ }^{53}$ F. García Martínez and Eibert J.C. Tigchelaar (eds.), The Dead Sea Scrolls Study Edition, 2.741 .

${ }^{54}$ Pseudo-Macarius, The Fifty Spiritual Homilies and the Great Letter, 152. 
According to the homilist, the glory would be restored in humanity only later, in the event of the incarnation of Christ, which brings "perfect healing" to the wretched human nature. In this context, Moses' shining face appears to be an important, even if not a "final," step in the process of healing of human nature. ${ }^{55}$

An additional detail that connects Moses with Adam is that the homilist understands Adam's deprivation of the luminosity as the wound which requires healing. ${ }^{56}$ In II.20.1 and 20. 4-5, Macarius links the loss of the external luminous attire by Adam with the internal wound. The homilist tells that the human being who...

...is naked and lacks the divine and heavenly garment...is covered with the great shame of evil affections... since ... the enemy, when Adam fell, used such cunning and diligence that he wounded and darkened the interior man... man was, therefore, so wounded that no one else could cure him... ${ }^{57}$

Despite the extensive "usage" of the Moses typology in the Macarian discussion of the Adamic "wound," the whole purpose of this empoyment remains Christological. Here again Macarius uses Mosaic traditions as the mediative tool for his glory Christology.

The Homily II.20 recounts that Moses' "healing" was incomplete in comparison with the healing of Christ, since it was "external" and unable to heal the inner wound

${ }^{55}$ It is noteworthy that Macarius again follows here the established tradition which connects the glory of Moses and the glory of Christ. The beginning of such a tradition can be found in 2 Cor 3:7-4:6. See: J.A. Fitzmyer, S.J., Glory Reflected on the Face of Christ (2 Cor 3:7-4:6) and a Palestinian Jewish Motif // JTS 42 (1981) 630-644; A. Orlov and A. Golitzin, Many Lamps are Lightened from the One: Paradigms of the Transformation Vision in the Macarian Homilies // Vigiliae Christianae 55 (2002) forthcoming. The Synoptic accounts of Christ's transfiguration seem to be also influenced by the Moses typology. Several details in the accounts serve as important reminders of Mosaic tradition(s): the vision took place on a mountain, the presence of Moses, a bright cloud that enveloped the visionaries, a voice which came out of the cloud, and the shining face of Christ. On Moses typology in the Synoptic accounts of the Transfiguration, see: J.A. McGuckin, The Transfiguration of Christ in Scripture and Tradition (Lewiston, 1986) (Studies in the Bible and Early Christianity, 9) 1-19; J. Markus, The Way of the Lord (Louisville, 1992) 80-93; M.E. Thrall, Elijah and Moses in Mark's Account of the Transfiguration // NTS 16 (1969-70) 305-17.

${ }^{56}$ It should be noted that despite the fact that the motif of Adam's luminous clothing is widespread in Aramaic and Syriac milieux, the conflation of this theme with the imagery of healing seem unique. See S. Brock, Clothing Metaphors as a Means of Theological Expression in Syriac Tradition, 1140.

\footnotetext{
${ }^{57}$ Pseudo-Macarius, The Fifty Spiritual Homilies and the Great Letter, 151.
} 
inflicted by Satan at the Fall. In II.32.4, Macarius sums up the Mosaic argument by telling that:

\begin{abstract}
...Moses, having been clothed in the flesh, was unable to enter into the heart and take away the sordid garments of darkness. ${ }^{58}$
\end{abstract}

Although Macarius tries to diminish the significance of Moses' shining face in the process of healing the human heart, he still seems to draw heavily on the Jewish traditions similar to $4 Q 374$, where Moses is depicted as the healer of the darkened human nature. $^{59}$

\title{
Conclusion
}

It should be noted in conclusion that the examination of the Adam-Moses connection in the Macarian Homilies and in the Qumran fragments might be mutually beneficial for a better understanding of both textual corpora.

First, the evidences to Adamic and Mosaic accounts found in the Macarian writings can extend the possible scope of the traditions which were preserved in the Dead Sea Scrolls materials in a very fragmentary form. In the light of the Macarian evidence, which provided an additional context for such traditions, it is not unreasonable to suggest that the passage from $4 Q 374$ might speak about the healing power of Moses' glorious face as healing the "wound" of Adam in the weak human nature. Therefore, in $4 Q 374$, as well as in $4 Q 504$, one might encounter a very early tradition depicting Moses as the glorious counterpart of Adam, the theme that later became a famous leitmotif in numerous Jewish and Christian materials. Despite that the Qumran passage about the healing in $4 Q 374$ lacks any reference to Adam or to his glorious garments, its close

\footnotetext{
${ }^{58}$ Pseudo-Macarius, The Fifty Spiritual Homilies and the Great Letter, 198.

${ }^{59}$ The Macarian Homilies, therefore, can be seen as the set of the intense polemics with the Jewish developments.
} 
affinities with the later Macarian evidence, where such connections are explicitly made, seem to clarify the proper meaning of the Qumran reference.

Second, it is also evident that both $4 Q 504$ and $4 Q 374$ can provide further insights for the background of the Adamic and Mosaic traditions in the Macarian Homilies. Despite their fragmentary character, these Qumran evidences about Adam and Moses help one see that the Macarian employment of the Mosaic traditions has in fact a strong polemical nature. The Syrian father seems to try to diminish the significance of Moses' "glorification" in the process of "healing" human nature, depicting it as the external covering unable to heal the inner wound caused by the Adamic transgression. However, the testimony to the Mosaic tradition found in $4 Q 374$ demonstrates that the emphasis on the internal character of the healing was already made at Qumran, where Moses' luminosity was depicted to be potent to heal the human heart.

Marquette University, Milwaukee WI 53233 USA 